\title{
Analisis kemampuan berpikir kritis dan kreatif dalam pemecahan masalah matematika berdasarkan kemampuan matematika siswa
}

\author{
A. Sri Mardiyanti Syam ${ }^{\mathrm{a}, 1, *}$ \\ ${ }^{a}$ IAIN Bone, Jl. HOS Cokroaminoto, Kab. Bone, Indonesia \\ 1 diyantisyam@gmail.com* \\ * Korespondensi Penulis
}

Article history

Received June 26, 2020

Revised June 26, 2020

Accepted June 27, 2020

Available Online June 30, 2020

Keywords

Critical thinking

Creative thinking

Problem solving

Mathematics ability
The study is descriptive qualitative, which aimed at describing critical thinking ability and creative thinking in solving problems based on Mathematics ability of students. The research subjects were the entire students of grade XII at SMAN 10 Bone of the first semester academic year 2019/2020 which consisted of 2 students who have high Mathematics ability and 2 students who have low Mathematics ability. Data were collected by using test of Mathematics ability, test of critical thinking to measure critical thinking ability, test of creative thinking to measure students' creative thinking and interview. The results of the study reveal that students who have high Mathematics ability can meet four indicators of critical thinking ability in solving problems, namely able to formulate main issues and reveal facts, able to detect bias and determine the concept to solve the questions, able to work on the questions based on the plan, able to recheck the answers, able to utilize other methods, and draw conclusion. Students who have low Mathematics ability can meet three indicators of critical thinking ability in solving problems, namely able to formulate main issues and reveal facts, able to detect bias and determine the concept to solve the questions, and able to work on questions based on the plan. Students who have high Mathematics ability can meet three indicators of creative thinking ability in solving problems, namely fluency, flexibility, and originality. Students who have low Mathematics ability cannot meet flexibility criteria, namely giving more than one answers (various) in counting process and the results are correct; similar to the originality criteria, namely the students' ability to answer the problems using their own mind in a unique way. 
Penelitian ini adalah penelitian kualitatif deskriptif yang bertujuan untuk mendeskripsikan kemampuan berpikir kritis dan kreatif dalam memecahkan masalah matematika berdasarkan kemampuan matematika siswa. Subjek penelitian merupakan siswa kelas XII SMAN 10 Bone tahun pelajaran 2019/2020 terdiri dari 2 orang siswa berkemampuan matematika tinggi dan 2 orang siswa berkemampuan matematika rendah. Pengambilan data dilakukan dengan menggunakan tes kemampuan matematika, tes berpikir kritis untuk mengukur kemampuan berpikir kritis, tes berpikir kreatif untuk mengukur kemampuan berpikir kreatif siswa, dan wawancara. Hasil penelitian ini menunjukkan siswa berkemampuan matematika tinggi dapat memenuhi empat indikator kemampuan berpikir kritis dalam memecahkan masalah, yaitu mampu merumuskan pokok-pokok permasalahan dan mengungkapkan fakta yang ada, mampu mendeteksi bias dan menentukan konsep untuk menyelesaikan soal, mampu mengerjakan soal sesuai rencana, mampu memeriksa kembali jawaban, menggunakan cara lain, dan menarik kesimpulan. Siswa berkemampuan matematika rendah dapat memenuhi tiga indikator kemampuan berpikir kritis dalam memecahkan masalah, yaitu mampu merumuskan pokok-pokok permasalahan dan mengungkapkan fakta yang ada, mampu mendeteksi bias dan menentukan konsep untuk menyelesaikan soal dan mampu mengerjakan soal sesuai rencana Siswa berkemampuan matematika tinggi dapat memenuhi tiga indikator kemampuan berpikir kreatif dalam memecahkan masalah yaitu kelancaran, keluwesan dan originalitas.Siswa berkemampuan matematika rendah tidak dapat memenuhi kriteria Keluwesan yaitu memberikan jawaban lebih dari satu cara (beragam) proses perhitungan dan hasilnya benar. Begitupun pada kriteria originalitas yaitu kemampuan siswa menjawab masalah dengan pemikiran sendiri dan menunjukkan sesuatu yang unik.

This is an open access article under the CC-BY-SA license.

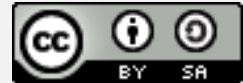

\section{Pendahuluan}

Kemampuan berpikir, baik berpikir kritis dan kreatif menjadi hal yang sangat penting dalam bidang pendidikan dewasa ini. Terbukti dari berbagai upaya pemerintah dalam pengambilan kebijakan di bidang pendidikan yang memasukkan kedua komponen ini ke dalam berbagai kegiatan pendidikan baik yang dimuat dalam kurikulum, strategi pembelajaran maupun perangkat pembelajaran lainnya. Upaya tersebut dimaksudkan agar siswa dapat dilatihkan keterampilan yang dapat mengembangkan kemampuan kritis dan kreatif dalam pemecahan masalah. Dengan demikian dunia pendidikan akan memberikan kontribusi yang besar terhadap pengembangan SDM yang kreatif, kritis dan memiliki kemampuan pemecahan masalah yang unggul untuk menjalani masa depan yang dinamis, sarat tantangan, dan penuh kompetisi.

Berpikir secara umum dapat diartikan sebagai kegiatan mental seseorang ketika dihadapkan pada suatu masalah atau situasi yang harus dipecahkan. Seiring dengan bertambahnya usia dan berkembangnya lingkungan sosial, masalah yang dihadapi seseorang menjadi semakin luas dan kompleks. Untuk bertahan pada kondisi tersebut, seseorang perlu memiliki kemampuan berpikir kritis dan kreatif karena dengan memiliki kemampuan tersebut ia akan lebih mudah untuk menghadapi dan menyelesaiakan masalah tersebut (Happy, 2014).

Tingkatan berpikir pada siswa dapat dibagi menjadi dua, yakni berpikir tingkat dasar dan berpikir tingkat tinggi. Menurut Resnick dalam (Thompson, 2008) berpikir tingkat dasar (lower order thinking) hanya menggunakan kemampuan berpikirnya terbatas pada hal-hal rutin dan bersifat mekanis. Sedangkan, berpikir tingkat tinggi (higher order thinking) membuat peserta didik dapat menginterpretasikan, menganalisa atau bahkan memanipulasi informasi sebelumnya sehingga tidak monoton dalam menyelesaikan masalah. 
Dalam proses belajar mengajar, kemampuan berpikir dapat dikembangkan dengan memperkaya pengalaman belajar yang bermakna melalui persoalan pemecahan masalah. Siswa dituntut memiliki kemampuan berpikir kritis, kreatif, logis, dan sistematis (Herman, 2007; Hidayat, 2011). Sehingga, kemampuan berpikir, baik berpikir kritis maupun berpikir kreatif merupakan kemampuan yang penting untuk dimiliki siswa agar siswa dapat memecahkan persoalan-persoalan yang dihadapi dalam dunia yang senantiasa berubah. Dengan demikian, pengembangan kemampuan berpikir, baik berpikir kritis maupun berpikir kreatif merupakan suatu hal yang penting untuk dilakukan dan perlu dilatihkan pada siswa mulai dari jenjang pendidikan dasar sampai jenjang pendidikan menengah. (Dilla, 2018; Hidayat, 2012; Istianah, 2013).

Mata pelajaran Matematika merupakan mata pelajaran wajib yang diberikan kepada semua siswa dengan tujuan agar dapat membekali kemampuan berpikir logis, analitis, sistematis, kritis, dan kreatif, serta kemampuan bekerjasama (Depdiknas, 2007). Kompetensi berpikir krtitis dan kreatif secara umum dalam matematika merupakan bagian keterampilan hidup yang sangat diperlukan siswa dalam menghadapi kemajuan IPTEKS yang semakin pesat serta tantangan, tuntutan dan persaingan global yang semakin pesat.

Perbedaan antara berpikir kreatif dan berpikir kritis dapat ditilik dari dua aspek. Pertama, berpikir kreatif bersifat intuitif yang berbeda dengan berpikir kritis (analitis) yang didasarkan pada logika, dan kedua memandang berpikir kreatif merupakan kombinasi berpikir yang analitis dan intuitif. Berpikir yang intuitif artinya berpikir untuk mendapatkan sesuatu dengan menggunakan naluri atau perasaan (feelings) yang tiba-tiba (insight) tanpa berdasar fakta-fakta yang umum. Pandangan pertama cenderung dipengaruhi oleh pandangan terhadap dikotomi otak kanan dan kiri yang mempunyai fungsi berbeda, sedang pandangan kedua melihat dua belahan otak bekerja secara sinergis bersama-sama yang tidak terpisah. (Siswono, 2008).

Berdasarkan uraian di atas kemampuan berpikir kritis dan kreatif menjadi sangat penting dimiliki dalam kaitannya terhadap kompetensi pemecahan masalah matematika. Untuk itu guru dituntut untuk menumbuhkan dan mealatihkan kemampuan berpikir kritis dan kreatif kepada siswasiswanya. Melalui hal tersebut, siswa dapat menemukan dan mengeksplorasi gagasan-gagasan baru dalam pemecahan masalah matematika dalam proses pembelajaran.

Observasi yang dilakukan penulis di SMAN 10 Bone menunjukkan hampir seluruh siswa pada satu kelas di kelas XII tidak mampu melakukan analisa dan tidak mampu mengembangkan informasi yang diberikan guru matematikanya. Mereka hanya bisa menghafal dan mengingat kembali informasi tersebut. Padahal menganalisis dan mengembangkan informasi yang diberikan guru adalah salah satu kategori berpikir kritis dan kreatif yang harus dicapai. Berdasarkan hal tersebut, penulis ingin melakukan suatu penelitian yang bertujuan untuk "Mengungkap Kemampuan Berpikir Kritis dan Kreatif dalam Pemecahan Masalah Matematika Berdasarkan Kemampuan Matematika Siswa"

Craver menyatakan bahwa berpikir kritis matematika berbeda dengan berpikir kritis pada bidang lainnya secara epistemologi (Mayadiana, 2009). Senada dengan itu, McPack berpendapat, beragamnya berpikir kritis dari bidang ke bidang dikarenakan adanya situasi berbeda. Hal ini kemudian menjadi penyebab munculnya beragam keyakinan akan apa itu berpikir kritis. Sebagai contoh, Ennis berpendapat mengenai perbedaan karakteristik penalaran yang baik pada tiap bidang. Misalnya, matematika hanya menerima pembuktian deduktif guna menyusun kesimpulan akhir.

Adapun indikator kemampuan berpikir kritis dalam pemecahan masalah yang akan digunankan dalam penelitian ini adalah Indikator berpikir kritis yang diturunkan dari aktivitas kritis menurut Ennis (1996) ada lima yaitu (1) mampu merumuskan pokok-pokok permasalahan; (2) mampu mengungkap fakta yang dibutuhkan dalam menyelesaikan suatu masalah; (3) mampu memilih argumen logis, relevan, dan akurat; (4) mampu mendeteksi bias berdasarkan sudut pandang yang berbeda; dan (5) mampu menentukan akibat dari suatu pernyataan yang diambil sebagai suatu keputusan.

Berpikir kreatif merupakan suatu proses yang dialami seseorang ketika ia memunculkan atau mendatangkan suatu gagasan atau ide baru. ide baru ini merupakan gabungan ide-ide yang belum pernah diwujudkan sebelumnya (Siswono, 2008). Pehkonen (1997) mengartikan berpikir kreatif sebagai suatu gabungan antara berpikir logis dan berpikir divergen yang didasarkan pada intuisi tetapi masih dalam kesadaran. Pengertian tersebut menjelaskan bahwa dalam berpikir kreatif untuk 
menghasilkan ide diperlukan pikiran logis dan intuitif. Keseimbangan antara logika dan intuisi sangat penting. Jika menempatkan deduksi logis terlalu banyak, maka ide-ide kreatif akan terabaikan. Dengan demikian untuk memunculkan kreativitas diperlukan kebebasan berpikir tidak di bawah kontrol atau tekanan.

Berdasarkan beberapa pandangan ahli mengenai berpikir kreatif dan untuk kepentingan penelitian, maka pengertian berpikir kreatif ditekankan pada proses/tahap-tahap berpikir kreatif yang mengacu pada: (1) Kefasihan (fluency), (2) Fleksibilitas (flexibility) (3) Keaslian (Originality). Fluency dalam pemecahan masalah diartikan sebagai kemampuan siswa dalam memecahkan masalah dengan beragam cara yang benar. Jawaban dikatakn beragam, apabila jawaban-jawaban tampak berlainan tetapi memiliki ide yang sama atau mengikuti pola tertentu. Flexibility dalam pemecahan masalah diartikan sebagai kemampuan siswa dalam memecahkan masalah dengan berbagai cara yag berbeda dan benar. Jawaban dikatakn berbeda, jika jawaban-jawaban tampak berlainan, tidak memiliki ide yang sama atau mengikuti pola tertentu. Originality dalam pemecahan masalah diartikan sebagai kemampuan siswa menjawab masalah yang tidak biasa dilakukan oleh siswa pada tingkat pengetahuannya atau jawaban yang diberikan belum pernah diperoleh sebelumnya. Jawaban dikatakan tidak pernah diperoleh sebelumnya, jika tidak pernah diajarkan oleh gurunya, tidak pernah dipelajari lewat buku, internet, dan tidak pernah didiskusikan dengan temantemannya. Kemampuan siswa untuk melahirkan ungkapan yang baru dan unik, memikirkan caracara yang tak lazim untuk mengungkapkan diri dan membuat kombinasi yang tak lazim dari bagian atau unsur-unsur. Keaslian jawaban atau cara penyelesaian terkait dengan berapa siswa yang memberikan jawaban atau cara penyelesaian tersebut. Semakin jarang siswa memberikan suatu jawaban yang sama atau cara penyelesaian yang sama, semakin tinggi tingkat keaslian jawaban tersebut. Namun aspek ini juga tetap harus mempertimbangkan kesesuaian dan kemanfaatan jawaban.

\section{Metode}

\subsection{Jenis Penelitian}

Penelitian ini merupakan jenis penelitian kualitatif deskriptif. Pendeskripsian ini ditelusuri dari hasil tes berpikir kritis dan kreatif matematis siswa serta dari hasil wawancara siswa. Setelah data diperoleh, kemudian dianalisis dan ditafsirkan kemudian menjadi deskripsi hasil dari penelitian yang dilakukan.

\subsection{Waktu dan Tempat Penelitian}

Subjek penelitian diperoleh dengan menggunakan teknik purposive sampling, yaitu teknik pengambilan sampel dengan pertimbangan tertentu yaitu berdasarkan kemampuan awal. Subjek dalam penelitian ini diambil dari kelas XII SMAN 10 Bone tahun pelajaran 2019/2020. Subjek yang terpilih dalam penelitian ini terdiri dari 4 orang yang diambil dari 33 siswa kelas XII MIA 1 yang telah selesai mempelajari materi dimensi tiga. Penetapan subjek penelitian ini berdasarkan hasil tes siswa berkemampuan matematika kategori tinggi dan rendah. Selanjutnya dipilih masing-masing 2 siswa berkemampuan matematika tinggi dan 2 siswa berkemampuan matematika rendah.

\section{Hasil dan Pembahasan}

\subsection{Kemampuan Berpikir Kritis-Subjek Berkemampuan Matematika Tinggi}

Pada bagian ini dilakukan perbandingan dan analisis data tentang tingkat berpikir subjek berkemampuan matematika tinggi dalam menyelesaikan soal dimensi tiga. Berdasarkan analisis data yang diperoleh dalam TBK, subjek berkemampuan matematika tinggi mampu merumuskan pokokpokok permasalahan dan mengungkap fakta yang dibutuhkan. Subjek dapat menyebutkan informasi apa yang diketahui dan ditanyakan dengan bahasa sendiri. Hal ini tergambar dari hasil TBK dan wawancara sebagai berikut.

P-001 : Dari soal nomor 1, informasi apa yang bisa kamu dapatkan?

T-001 : Dari soal nomor 1 saya dapat mengetahui bahwa jarak itu diambil dari rute terpendek. Jadi meskipun ada berbagai macam rute yang bisa di tempuh dari A ke C, tetapi untuk menentukan jarankya kita ambil rute terpendek 


\section{P-002 : Jarak manakah yang kamu maksud? \\ T-002 : Jarak A ke C}

Dalam menentukan rencana penyelesaian pada subjek berkemampuan matematika tinggi mampu menentukan konsep yang digunakan, mampu mengetahui semua informasi dapat digunakan atau tidak. Sebagaimana hasil wawancara peneliti dengan subjek sebagai berikut.

\section{P-010 : Untuk mendapatkan jarak lampu ke salah satu sudut lantai kamar, cara apa yang kamu gunakan? \\ T-010 : Pertama harus cari OE. Setelah itu bisa menggunakan OE dan AE ke rumus phytagoras. Maka di dapat mi OA.}

Transkrip wawancara di atas menegaskan bahwa subjek mampu menentukan konsep yang digunakan dan mampu mendeteksi bias dengan menerapkan cara dan rumus yang sesuai. Selanjutnya, saat melaksanakan rencana penyelesaian, subjek berkemampuan matematika tinggi mampu mengerjakan soal sesuai rencana dan mampu mengungkapkan pendapat yang logis. Hal ini tampak saat subjek mampu memberikan argument yang jelas terhadap apa yang kurang dan apa yang dibutuhkan pada soal. Di samping itu, subjek mengerjakan soal sesuai dengan rencana awal.

$\begin{array}{ll}\text { P-015 : } & \text { Saat kamu melihat soal, apa sudah terfikir seperti apa langkah yang } \\ & \text { harus kamu ambil untuk menjawabnya? } \\ \text { T-015 : } & \text { Iya kak, saya langsung kepikiran cara penyelesaiannya dengan } \\ & \text { menggambarkannya dulu } \\ \text { P-016 : } & \text { Apakah rencana awal itu sesuai dengan apa yang kamu kerjakan } \\ & \text { hingga terakhir? } \\ \text { T-016 : } & \text { Iya kak tetap pakai cara yang terpikir sejak awal. Kan yang dicari } \\ & \text { jarak lampu ke salah satu sudut lantai kamar. Jadi yang mewakili itu } \\ & \text { seperti yang saya gambar, panjangnya OA. Saya cari EO dulu. } \\ & \text { Dimana EO itu setengah dari EG. sebelum itu cari EG dulu } \\ & \text { menggunakan Phytagoras. Setelah itu, cari mi OA gunakan } \\ & \text { phytagoras juga. Jadi yang saya dapat OA }=2 \text { akar } 6\end{array}$

Subjek berkemampuan tinggi juga menunjukkan kemampuannya mengevaluasi solusi pada proses penyelesaian soal. Subjek pun menguji dan memerika kembali jawaban pada proses penyelesaian soal.
P-021 : Apakah kamu memeriksa kembali jawaban setelah memperoleh hasilnya?
T-021: Iya kak.
P-022 : Apakah setelah mendapat jawabannya kamu membuktikan kebenarannya mengunakan cara lain?
T-022 : Awalnnya saya yakin, namun saya coba mengunakan titik lain untuk membuktikan kebenarannya, dan ternyata sesuai.

Berdasarkan hasil tugas dan hasil wawancara dengan subjek berkemampuan tinggi dapat dikatakan subjek memeriksa kembali jawaban menggunakan cara lain dan mampu menarik kesimpulan. Sehingga dapat disimpulkan bahwa, subjek berkemampuan tinggi dapat memenuhi empat indikator kemampuan berpikir kritis yakin: (1) Merumuskan pokok-pokok permasalahan dan mengungkapkan fakta yang ada; (2) Menentukan konsep yang digunakan dan mampu mendeteksi bias; (3) Mengerjakan sesuai rencana awal dan mengungkapkan argument logis; (4) Memeriksa kembali jawaban, menggunakan cara lain, dan menarik kesimpulan.

\subsection{Kemampuan Berpikir Kritis-Subjek Berkemampuan Matematika Rendah}

Berdasarkan analisis data yang diperoleh dalam TBK, subjek berkemampuan matematika rendah mampu merumuskan pokok-pokok permasalahan dan mengungkap fakta yang dibutuhkan. Hasil wawancara berikut menunjukkan subjek berkemampuan rendah mampu menyebutkan informasi apa yang diketahui dan ditanyakan dengan bahasanya sendiri dan dapat memahami apa yang ditanyakan 
dan diketahui pada soal. Sehingga dapat disimpulkan, subjek memenuhi indikator mampu merumuskan pokok permasalahan dan mengungkapkan fakta yang dibutuhkan.

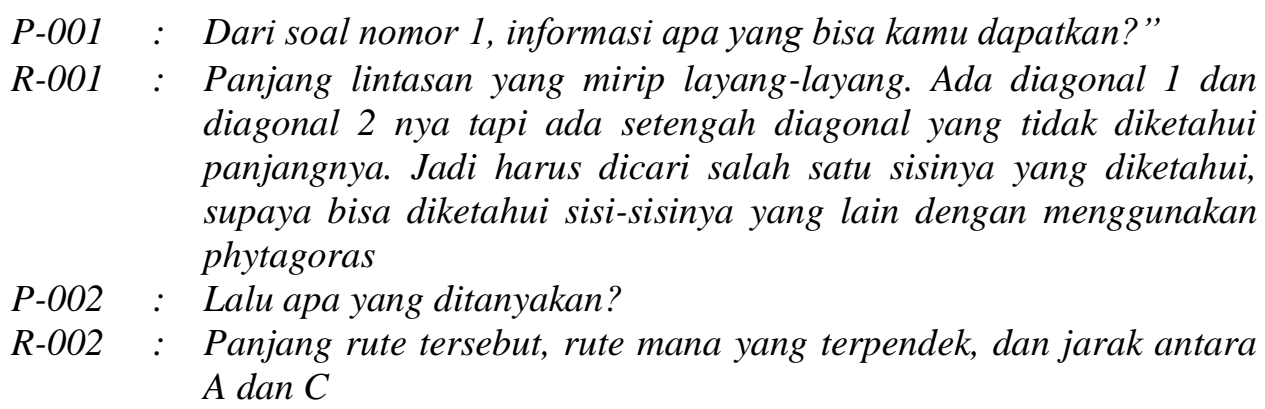

Dalam menentukan rencana penyelesaian pada subjek berkemampuan matematika rendah mampu menentukan kosep yang digunakan namun ada kekeliruan dalam memahami soal, sehingga tidak mampu mengetahui semua informasi dapat digunakan atau tidak. Selain dari hasil TBK subjek, hal ini dibuktikan dengan hasil wawancara sebagai berikut.

\section{$P-013$ : untuk mencari rute terpendek, bagaimana? \\ R-013 : Harus diketahui semua panjang lintasan dengan cara phytagoras}

Dalam melaksanakan rencana subjek $\mathrm{R}$ mampu mengerjakan soal sesuai rencana namun tidak mampu mengungkapkan argument yang logis. Sedangkan, dalam memeriksa kembali jawaban, subjek berkemampuan matematika rendah memeriksa kembali jawaban tetapi tidak menggunakan cara lain.
P-021 : Apakah kamu memeriksa kembali jawaban setelah memperoleh hasilnya?
$R-021$ : iye
P-022 : Apakah setelah mendapat jawabannya kamu membuktikan kebenarannya mengunakan cara lain?
R-022 : Tidak, hasilnya hanya ku hitung ulang dengan cara yang sama

Berdasarkan hasil TBK subjek $\mathrm{R}$ dan hasil wawancara, terlihat bahwa subjek mengevaluasi solusi pada proses penyelesaian soal. Subjek menguji dan memeriksa kembali jawaban pada proses penyelesaian soal. Namun tidak menggunakan cara lain. Sehingga secara umum, kemampuan berpikir kritis subjek berkemampuan rendah hanya memenuhi dua indikator saja, yakni indikator (1) merumuskan pokok-pokok permasalahan dan mengungkapkan fakta yang ada; dan (2) menentukan konsep yang digunakan dan mampu mendeteksi bias.

\subsection{Kemampuan Berpikir Kreatif-Subjek Berkemampuan Matematika Tinggi}

Subjek yang masuk dalam kategori sangat kreatif atau TBK 4 adalah subjek berkemampuan matematika tinggi. Hal ini karena kedua subjek memenuhi ketiga krieria yaitu fluency diliihat dari keberagaman jawaban, subjek memberikan lebih dari satu ide yang relevan dan penyelesaian yang benar dan jelas. Selain itu subjek juga dapat memahami apa yang ditanyakan dan diketahui pada soal. Berdasarkan hasil wawancara, terlihat bahwa hasil kerja subjek T memiliki pemahaman yang mendalam tentang permasalahan yang diberikan.
P-004 : Coba ceritakan, konsep-konsep, atau sifat-sifat matematika apa saja yang kamu anggap dapat digunakan untuk selesaikan itu soal no.1
T-004 : Konsep Trigonometri dan Phytagoras
P-005 : Coba jelaskan teknik apa yang kamu terapkan untuk menyelesaian soal!
T-005 : Tehnik untuk mencari jarak titik ke titik, titik ke garis, dan trigonometri, phytagoras

Selanjutnya, subjek mampu memberikan jawaban lebih dari satu cara(beragam) dan proses perhitungan atau hasilnya benar. Hal ini menunjukkan subjek memenuhi indikator fleksibilitas dari 
kemampuan berpikir kreatif. Sedangkan, originalitas subjek dapat dilihat dari kemampuannya menyebutkan kemungkinan-kemungkinan jawaban pada soal sebagaimana hasil wawancara berikut.

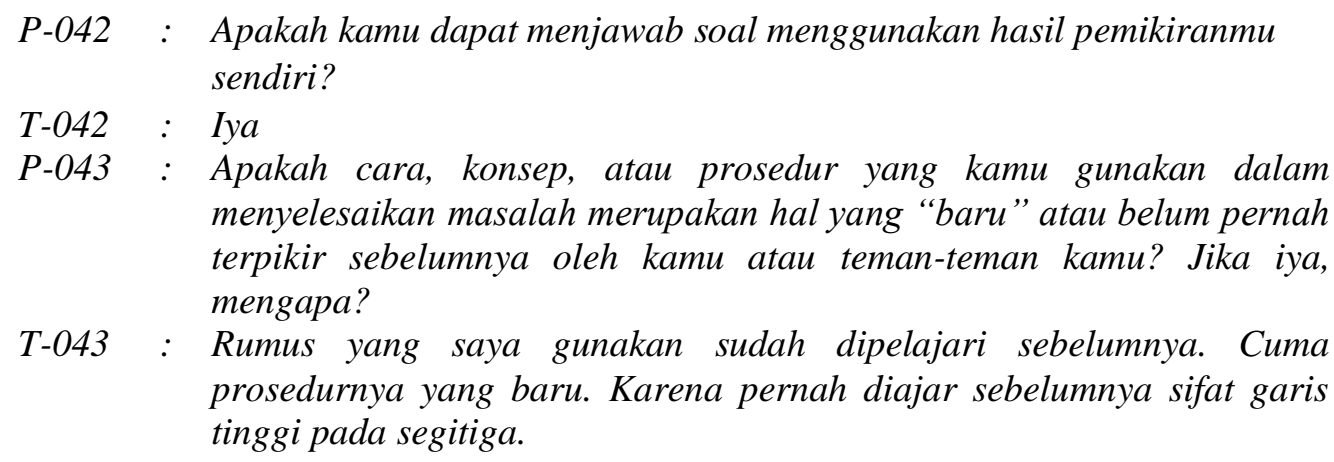

Berdasarkan hasil wawancara tersebut, subjek mampu memberikan jawaban dengan caranya sendiri, proses perhitungannya benar dan dapat memahami apa yang diinginkan soal. Konsepkonsep matematika yang telah mereka ketahui telah diterapkan sehingga subjek dapat menjawab pertanyaan dengan berbagai cara dan berbagai alternatif jawaban. Sehingga berdasarkan penelusuran hasil TKB dan wawancara, dapat disimpulkan bahwa subjek berkemampuan tinggi memenuhi seluruh indikator berpikir kreatif, yakni Fluency, Flexibility dan Originality.

Secara keseluruhan, hasi di atas sesuai dengan pendapat Nur Samsiyah et al. (2014) bahwa kemampuan berpikir kreatif siswa untuk kategori tinggi pada aspek berpikir lancar sangat baik karena siswa kategori tinggi mampu memunculkan lebih dari satu ide dalam menyelesaikan masalah matematika open-ended sehingga pada aspek berpikir lancar untuk siswa kategori tinggi tidak mengalami kesulitan. Untuk aspek berpikir luwes, siswa pada kategori tinggi berada pada kriteria baik artinya pada umumnya mampu menentukan satu cara dalam menyelesaikan masalah matematika open-ended. Siswa pada kategori tinggi untuk aspek keaslian juga berada pada kriteria baik dengan perkataan lain meskipun cara yang digunakan dalam menyelesaikan masalah dengan cara yang umum tetapi mengarah pada penyelesaian. Kemampuan pada aspek berpikir elaborative pada siswa kategori tinggi sangat baik, artinya siswa dapat memperjelas penyelesaian dengan rinci dan tepat sehingga pada aspek ini secara umum tidak mengalami kesulitan.

\subsection{Kemampuan Berpikir Kreatif-Subjek Berkemampuan Matematika Rendah}

Subjek berkemampuan rendah menunjukkan adanya fluency yang didapat dari hasil tugas dan wawancara. Subjek R menampakkan kemampuannya memberikan lebih dari satu ide yang relevan dan penyelesaian yang benar dan jelas sebagai berikut.

$P-004:$ Coba ceritakan, konsep-konsep, atau sifat-sifat matematika apa saja

yang kamu anggap dapat digunakan untuk selesaikan itu soal no.1
$P-006:$ Konsep Phytagoras
$R-006:$ Masih ada materi lain yang terkait selain yang kita sebutkan tadi?

Pada proses wawancara subjek $\mathrm{R}$ tidak dapat memberikan jawaban beragam, namun hasil perhitungannya benar. Selain itu, subjek $\mathrm{R}$ juga belum mampu memberikan jawaban dengan caranya sendiri. Sehingga, untuk subjek berkemampuan matematika rendah, tidak ada siswa yang masuk kategori TKB 4. Subjek R1 dan subjek R2 tidak dapat memenuhi kriteria flexibility yaitu memberikan jawaban lebih dari satu cara (beragam) proses perhitungan dan hasilnya benar. Begitupun pada kriteria originalitas yaitu kemampuan siswa menjawab masalah dengan pemikiran sendiri dan menunjukkan sesuatu yang unik.

P-022 : Ada cara lain yang bisa kamu gunakan tidak?

R-022 : Tidak ada bu. Itu satu-satu nya cara yang bisa digunakan 


\section{Simpulan}

Berdasarkan hasil temuan penelitian yang diperoleh, dapat disimpulkan bahwa (1) Siswa berkemampuan matematika tinggi dapat memenuhi empat indikator kemampuan berpikir kritis dalam memecahkan masalah, yaitu mampu merumuskan pokok-pokok permasalahan dan mengungkapkan fakta yang ada, mampu mendeteksi bias dan menentukan konsep untuk menyelesaikan soal, mampu mengerjakan soal sesuai rencana, mampu memeriksa kembali jawaban, menggunakan cara lain, dan menarik kesimpulan. (2) Siswa berkemampuan matematika rendah dapat memenuhi tiga indikator kemampuan berpikir kritis dalam memecahkan masalah, yaitu mampu merumuskan pokok-pokok permasalahan dan mengungkapkan fakta yang ada, mampu mendeteksi bias dan menentukan konsep untuk menyelesaikan soal dan mampu mengerjakan soal sesuai rencana(3) Siswa berkemampuan matematika tinggi dapat memenuhi tiga indikator kemampuan berpikir kreatif dalam memecahkan masalah yaitu kelancaran, keluwesan dan originalitas (4) Siswa berkemampuan matematika rendah tidak dapat memenuhi kriteria Keluwesan yaitu memberikan jawaban lebih dari satu cara (beragam) proses perhitungan dan hasilnya benar. Begitupun pada kriteria originalitas yaitu kemampuan siswa menjawab masalah dengan pemikiran sendiri dan menunjukkan sesuatu yang unik.

\section{Daftar Pustaka}

Departemen Pendidikan Nasional. (2007). Model-model Pembelajaran Matematika dan Ilmu Pengetahuan Alam. Jakarta: Direktorat PSLB.

Dilla, S. C., Hidayat, W., \& Rohaeti, E. E. (2018). Faktor Gender dan Resiliensi dalam Pencapaian Kemampuan Berpikir Kreatif Matematis Siswa SMA. Journal of Medives, 2(1), 129-136.

Ennis, R. H. (1996). Critical thinking (Vol. 14, pp. 48-51). Upper Saddle River, NJ: Prentice Hall.

Happy, N., \& Widjajanti, D, B. (2014). Keefektifan PBL Ditinjau dari Kemampuan Berpikir Kritis dan Kreatif Matematis Self-Esteem Siswa SMP. Jurnal Riset Pendidikan Matematika, Volume 1, Nomor 1

Herman, T. (2007). Pembelajaran Berbasis Masalah untuk Meningkatkan Kemampuan Berpikir Matematis Tingkat Tinggi Siswa Sekolah Menengah Pertama. Jurnal EDUCATIONIST No. I Vol. I.

Hidayat, W. (2012). Meningkatkan Kemampuan Berpikir Kritis dan Kreatif Matematik Siswa SMA Melalui Pembelajaran Kooperatif Think-Talk-Write (TTW). Seminar Nasional Penelitian, Pendidikan dan Penerapan MIPA.

Istinah, E. (2013). Meningkatkan Kemampuan Berpikir Kritis dan Kreatif Matematik dengan Pendekatan Model Elicing Activies (MEAs) Pada Siswa SMA. Infinity Jurnal Ilmiah Program Studi Matematika STKIP Siliwangi Bandung, Vol 2, No.1

Krulik, S., \& Rudnick, J. A. (1989). Problem Solving: A Handbook for Senior High School Teachers. Allyn \& Bacon/Logwood Division, 160 Gould Street, Needham Heights, MA 02194-2310.

Mayadiana, D. 2009. Suatu Alternatif Pembelajaran Kemampuan Berpikir Kritis Matematika. Jakarta: CakrawalaMaha Karya.

Pehkonen, E. (1997). The state of art in mathematical creativity. ZDM, 29(3), 63-67

Siswono, T. Y. E. 2008. Model Pembelajaran Matematika Berbasis Pengajuan dan Pemecahan Masalah untuk Meningkatkan Kemampuan Berpikir Kreatif. Surabaya: Unesa University Press.

Thompson, T. 2008. Mathematics Teachers' Interpretation of Higher-Order Thinking In Bloom's Taxonomy. International Electronic Journal of Mathematics Education, 3(2), 96-109.

Wilson, P. H., Mojica, G. F., \& Confrey, J. (2013). Learning trajectories in teacher education: Supporting teachers' understandings of students' mathematical thinking. The Journal of Mathematical Behavior, 32(2), 103-121. 